\title{
Transplantation of an alpine Carex-fen - a mitigation measure related to the construction of a reservoir in the Austrian Alps
}

\author{
Martin Schletterer ${ }^{1,2, *}$, Brigitte Kurz $^{3}$, Alexandra Schönegger ${ }^{1}$, Gregory Egger ${ }^{2,4,5}$ and \\ Klaus Feistmantl ${ }^{1}$ \\ ${ }^{1}$ TIWAG-Tiroler Wasserkraft AG, Innsbruck, Austria \\ ${ }^{2}$ Institute of Hydrobiology and Aquatic Ecosystem Management, University of Natural Resources \\ and Applied Life Sciences, Vienna, Austria \\ ${ }^{3}$ Ingenieurbüro für Landschaftsgestaltung und Ingenieurbiologie, Telfes i. Stubai, Austria \\ ${ }^{4}$ Naturraumplanung Egger, Klagenfurt, Austria \\ ${ }^{5}$ Institute of Geography and Geoecology, Karlsruhe Institute of Technology, Karlsruhe, Germany
}

\begin{abstract}
Translocations are applied in the context of infrastructure projects to preserve certain vegetation types. Within the EIA of a large hydropower project in the Austrian Alps, manifold mitigation measures were defined. Among those, the transplantation of about 1.4 ha Carex-fen at an altitude of about $2000 \mathrm{~m}$ was defined. One year before the start of the construction works in 2021, basic infrastructure (roads) was established and different ecological measures were undertaken, e.g. translocation of amphibians to newly constructed habitats as well as the transplantation of the Carex-fen. The turf was cut from the initial area with an adjusted excavator shovel, delivered to a wheel loader which brought each single turf immediately to the target area, where another excavator mounted the turf in a pre-arranged area. At the donor site more than $1 / 2$ of the area was based on wet gley, while especially areas in the vicinity of the river were based on fluvial gravel. With the 30 to $70 \mathrm{~cm}$ thick turfs also animals, e.g. Odonata, were transferred. Before the translocation a monitoring of the donor sites was carried out. The monitoring concept foresees a detailed monitoring of the newly established sites for 10 years. Herein we provide insights in the applied technology and summarize first results of the monitoring. Overall, our project is unique regarding the vegetation type, the technology, the size and the intensity of monitoring.
\end{abstract}

\section{Introduction}

In the context of infrastructure projects translocations are applied to preserve certain vegetation types $[1,2]$. The existing 780-MW hydropower plant Sellrain-Silz $(531 \mathrm{GWh})$ makes use of a total head of $1678 \mathrm{~m}$ in two stages and is among the largest Austrian hydropower plants [3]. The upper stage (pumped-storage plant Kühtai with Francis pump

*Corresponding author: martin.schletterer@tiwag.at 
turbines), with a head of more than $400 \mathrm{~m}$, can turbinate water $\left(80 \mathrm{~m}^{3} / \mathrm{s} ; 285 \mathrm{MW}\right)$ from the 60 million- $\mathrm{m}^{3}$ seasonal reservoir Finstertal to the 3 million- $\mathrm{m}^{3}$ equalizing reservoir Längental and pump water backwards $\left(60 \mathrm{~m}^{3} / \mathrm{s} ; 250 \mathrm{MW}\right)$ during times of energy surplus. The lower stage at Silz is high head power plant $(1257 \mathrm{~m})$ with Pelton turbines, with a total design discharge of $48 \mathrm{~m}^{3} / \mathrm{s}$ it equals to $495 \mathrm{MW}$ [4].

In general, hydro-powerplants produce $\mathrm{CO}_{2}$ neutral energy and their flexibility enables the integration of other renewable sources (wind, photovoltaic) [5]. In this context in 2004 first plans for an extension of the existing hydropower plant Sellrain-Silz were made and in 2009 the Environmental Impact Assessment (EIA) was handed in for approval. The project was approved in 2016 by the Tyrolean government (first instance) and in 2019 by the Federal Administrative Court (second instance). The project foresees the construction of the new 31 million- $\mathrm{m}^{3}$ reservoir Kühtai, as well as additional water intakes from surrounding valleys [6]. In future water will be turbinated and pumped between the existing Finstertal reservoir and the new Kühtai reservoir via the new Kühtai 2 pumped storage power plant. Overall, the expansion allows to improve the efficiency of the existing facility and will increase the reservoir capacity of the entire power plant group by $50 \%$.

While different vegetation types are transplaned commonly [1, 2], regarding fens and mires only a few projects were carried out so far. In Switzerland related to the re-construction of the airport Zurich-Kloten (runway 14/32), between 1972 and 1973 fens were transplanted along distances of $100 \mathrm{~m}$ up to $6.5 \mathrm{~km}$ in order to preserve them $[7,8]$. Turf with a size of $0.9 \times 1.3 \mathrm{~m}$, a thickness of about $0.4 \mathrm{~m}$ with a weight of up to $1 \mathrm{t}$ were transported via rails from the donor to the receiving site - globally, this was the first transplantation of a fen in this scale with specific costs of $300-500$ Swiss franc (CHF) $/ \mathrm{m}^{2}$ [9]. The receiving sites were selected to ensure similar habitat features (especially water and nutrient balance). Analyses showed that some species like orchids, disappeared, but the overall transplantation was successful [9]. The biggest transplanted units ("Klötzliwiese"), one with Carex diandra and the other with Schoenus nigricans are nowadays part of the protected area "Klotener Riet" of national importance [10].

Within the EIA of a large hydropower project in the Austrian Alps, the extension of the HPP Sellrain-Silz, manifold mitigation measures were defined. Among those, the transplantation of about 1.4 ha Carex-fen (a main complex with about 1.1 ha and additional smaller spots along the valley) at an altitude of about $2030 \mathrm{~m}$ was defined. This is related to the protection of fen habitats by the Tyrolean Nature Conservation Law (TNSchG 2005). In this context a transplantation is an ideal measure, as the relocation ensures that the biotope type is relocated and can fulfill within a short time period it's habitat functions.

Our project also allows analysing the development of the transplanted turf at the receiving sites and for the first time describes the transplantation of a Carex fen at a high altitude. The documentation of the applied method and first results related with this measure are summarized herein.

\section{Methods}

\subsection{Study site}

The valley Längental is located in the Ötztal Alps, a mountain range in the Central Eastern Alps, close to the ski resort Kühtai and the existing HPP Sellrain-Silz (Fig. 1). In 2008 extensive biotope-type analyses were carried out in the whole valley related to the EIA for the extension of the HPP Sellrain-Silz. The major vegetation types are characterized by a mosaic of dwarf shrubs (Rhododendron ferrugineum, Vaccinium spp.) and Narduus 
grassland. At bottom the valley, in the vicinity of the river a Carex fen was present. In the framework of the EIA also the vegetation history of the valley was assessed by means of pollen analyses [11].

According to the climate classification of Köppen and Geiger in the study area a Dfb climate is present (cold / moderate), with a mean temperature of $0.9^{\circ} \mathrm{C}$ and a precipitation of $1653 \mathrm{~mm}$ [https://de.climate-data.org/europa/oesterreich/tirol/kuehtai-111749/]. The coldest month is January with a mean temperature of $-9.3{ }^{\circ} \mathrm{C}$ and the warmest month is July with $10.6{ }^{\circ} \mathrm{C}$.

In 2020 - between July and September - the Carex fen from the donor site in the middle of the valley Längental was transplanted on two receiving sites: one in the end of the valley (between $2140 \mathrm{~m}$ and $2200 \mathrm{~m}$ ), which required a transport of about $1.6 \mathrm{~km}$ and another one downstream of the Längental reservoir at "Hemerwaldalm", which required a transport of about $3.2 \mathrm{~km}$ (Fig. 1).

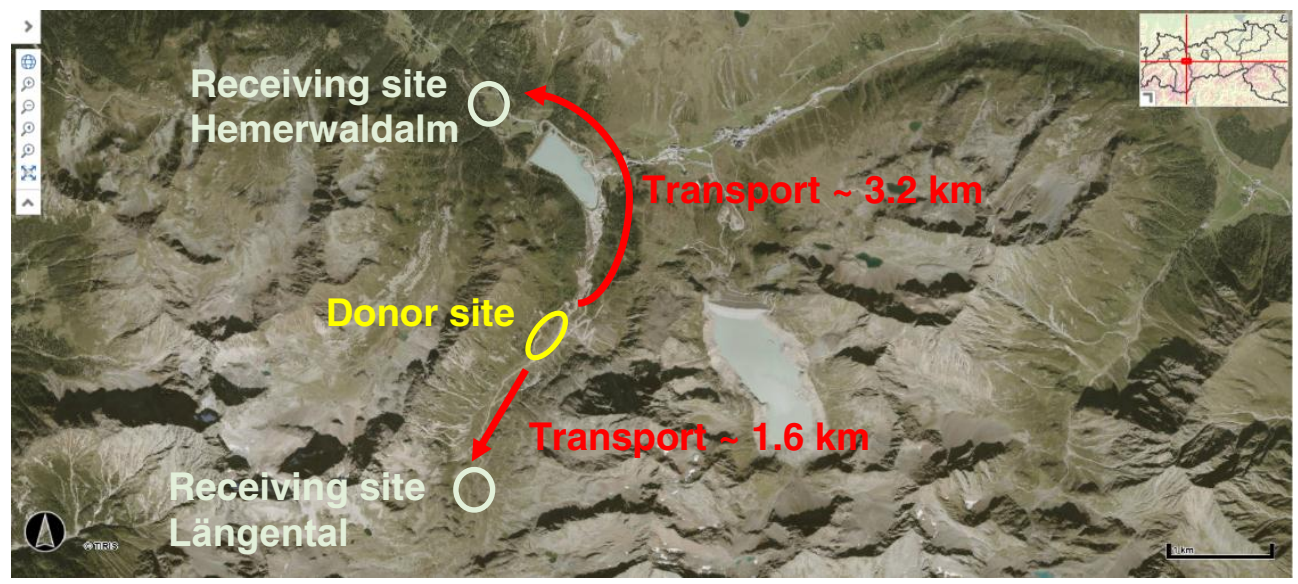

Fig. 1. Location of the donor site and the receiving sites

\subsection{Analyses of the Vegetation in the valley and definition of the mitigation measure "transplantation of the Carex-fen"}

Vegetation relevés according to [12] were carried out on eight sites ( $2 \times 2 \mathrm{~m})$ across the donor area for the planned fen transplantations, before the start of the manipulation. Due to the importance of the cryptogamic communities in the Längental, also the cryptogamic species were included in the surveys. The eight sampling areas were selected to record all essential fen types of the donor area. Vegetation relevés were recorded into the TurboVeg database [13] and compiled in the form of a vegetation table.

In accordance with the analogous methodology of the donor areas, vegetation surveys will be carried out in the two recieving sites in the rear Längental and at the Hemerwaldalm (Fig. 1). Monitoring will take place for the first time in 2021 and will be repeated after 3, 5 and 10 years after translocation.

\section{Results}

Surveys at the eight relevés of donor sites were conducted in July 2020. In total, 55 plant species could be identified. In addition to the typical species of the fens and headwater ponds 
such as Carex nigra, Viola palustris, Juncus filiformis, Eriophorum angustifolium, Eriophorum vaginatum, Saxifraga stellaris, Warnstorfia exannulata, Epilobium nutans and the mosses Aulacomnium palustre and Drepanocladus aduncus also species of the neighboring alpine pastures such as Nardus stricta, Agrostis rupestris, Phleum rhaeticum, Homogyne alpina, Leontodon helveticus, Potentilla erecta could be documented.

One year before the start of the construction works in 2021, basic infrastructure (roads) was established and different ecological measures were undertaken, e.g. translocation of amphibians to newly constructed habitats as well as the transplantation of the Carex-fen. For this transplantation two excavators (25 ton) and two wheel loaders (in order to ensure vibration-free transport) as well as operators and two workman were needed. The road infrastructure existed already. Transportation towards the receiving site Hemerwaldalm was carried out by trucks.

The lifting of the turf at the donor site was carried out with a specially equipped excavator (bucket with welded steel plate and rotary joint) in the presence of the ecological construction supervision. The recovered turf (size: 1 x $1.5 \mathrm{~m}$ ) with a thickness of at least $30 \mathrm{~cm}$ (mostly more than $50 \mathrm{~cm}$ ) were not temporarily stored, but brought immediately to the receiving sites (Fig. 02). Videos are available online [www.erneuerbareplus.at].

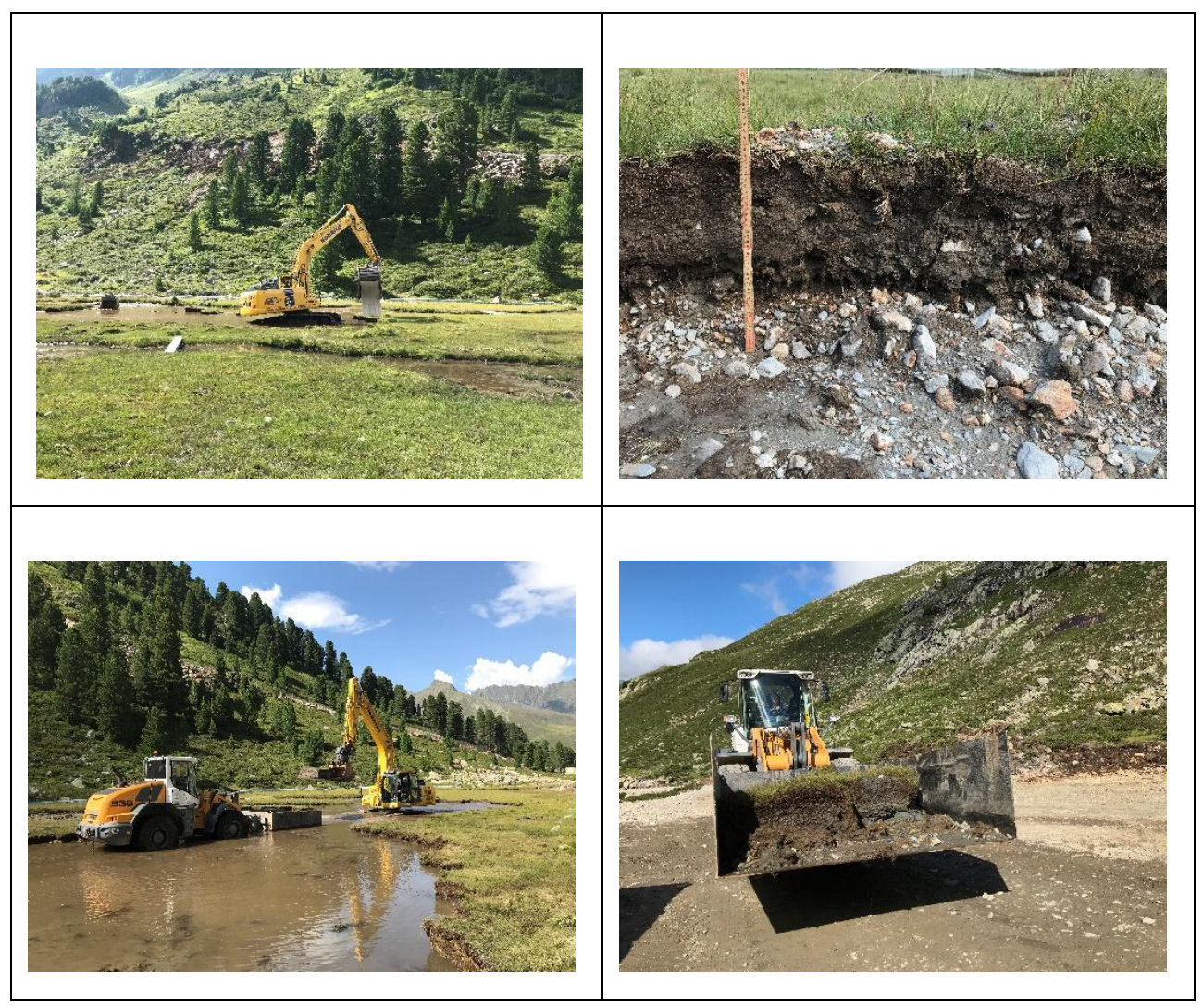

Fig. 2. Transplantation of an alpine Carex fen: Workflow at the donor site. (a) extraction of the turf at the donor site, (b) mean thickness of the turf was about $40 \mathrm{~cm}$ (based on fluvial gravel), $(\mathrm{c}+\mathrm{d}$ ) each piece was transferred immediately onto a wheel loader

As the largest part of the fen was in the surroundings of the river (meandering section), the removal had to be carried out in flooded areas. Thus the turf were recovered from the 
downstream end of the site, in order to avoid that fine sediments are washed out. More than $1 / 2$ of the area was based on wet gley, while especially areas in the vicinity of the river were based on fluvial gravel.

In summer 2020, the receiving sites were prepared (removal of the vegetation and soil up to $50 \mathrm{~cm}$ depth) and, where necessary, provided with a geosynthetic clay liner (Tektoseal ${ }^{\circledR}$ Clay NA $5000 \mathrm{AT}+$, Huesker) to ensure suitable habitats. The turf were transplanted with an interlocked structure and afterwards gaps (joints between turf) were filled with wet gley soil. A total of approximately 0.69 ha of the Carex-fen was transplanted into the rear valley (upstream of the new reservoir), approximately 0.5 ha were transplanted at receiving sites near the Hemerwald-Alm and approximately 0.2 ha were transplanted to an interim storage area (for 5 years) - thus the whole Carex-fen complex (1.4 ha) was transplanted (Fig. 03).

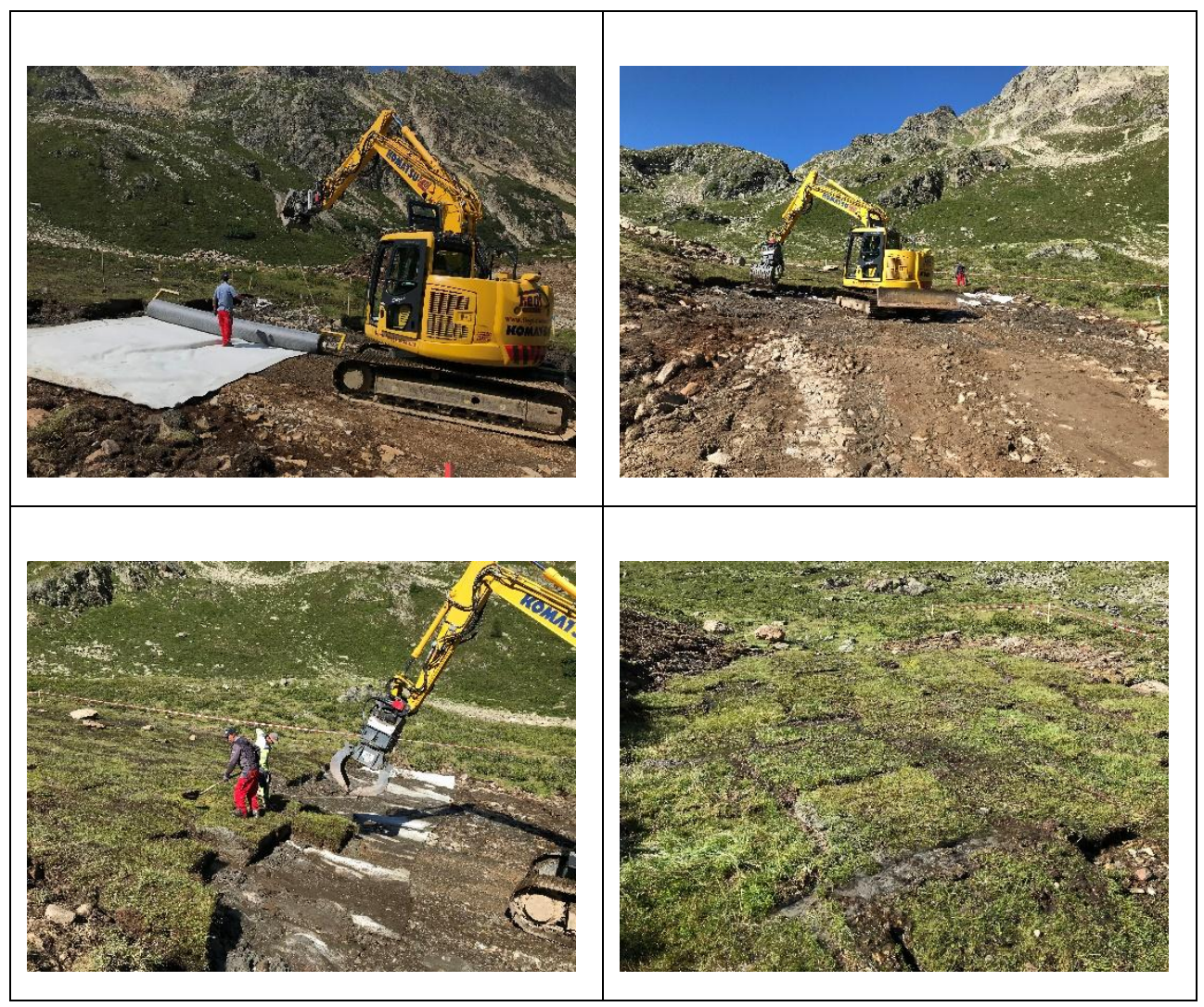

Fig. 3. Transplantation of an alpine Carex fen: Workflow at the receiving site. $(a+b)$ preparation of the underground, (c) positioning of the turfs, (d) mosaic right after the transplantation

One year after the receiving sites provide promising results - the turf survived and Carex and Eriophorum is flowering at the new locations. Further details will be made available after the monitoring campaigns. The costs for this measure amounted 1 Mio. $€$, thus the specific costs are about $100 € / \mathrm{m}^{2}$. In this context it needs to be considered that the road infrastructure existed or was built in the context of the main project. Also the turf were stable and did not require packing in fleece. Thus, if also road construction (to donar respectively receiving sites) would have been required or the turf would have required packing, the costs would be significantly higher. 


\section{Discussion}

So far, in Austria such transplantations of fens were made only in lower altitudes and with a smaller spatial extend. As far as we know, the described Carex-fen transplantion in the Längental is the largest measure of this type in Austria and thus at least a pilot project, which will be observed in the next few years through extensive monitoring, i.e. in the $1^{\text {st }}, 3^{\text {rd }}, 5^{\text {th }}$ and $10^{\text {th }}$ year after the translocation. The development objective will be achieved if, 10 years after the fen transplantations, the fen and wetland indicators have not decreased in abundance and no significant nutrient and land use indicators (as a result of grazing related to alpine pasture) evolved.

With this measure also larvae of dragonflies (Odonata) were transferred with the substratum in their new habitat. Within the assessments for the EIA, three dragonfly species were detected by visual observation and net catches (adults and larvae) in the valley: Enalagma cyathigerum (Charpentier, 1840), Aeshna juncea (Linnaeus, 1758) and Somatochlora alpestris (Sélys, 1840). During the pre-monitoring in 2020, also the occurrence of Leucorrhinia dubia was confirmed by visual observations. All detected species are similar in terms of their larval habitat. The translocation of larvae by transplanting turf is the most effective method, which has also the advantage that the entire biotope is relocated.

Beside the herein described measures, an additional measure related to the establishment of Carex fens is foreseen. The new reservoir will have a size of 59.4 ha and at the beginning of backwater, where the river Längentalbach enters, an area with shallow water will be established. In this area in the end of the construction phase, temporarily stored turf ( $0.2 \mathrm{ha})$ from the Carex fen, will be transplanted to this area (approximately $1.3 \mathrm{ha}$ ) in order to initiate the development of a Carex fen also in this area.

Overall, the herein described transplantation is unique regarding the vegetation type, the technology, the size and the intensity of monitoring.

\section{References}

1. P.W. Schwickert. Verpflanzen von Pflanzen bzw. Pflanzengesellschaften als Chance für den Naturschutz? Stand der Forschung und jüngste Unternehmungen. Natur und Landschaft. 67 (3), 111-114 (1992)

2. J.M. Bullock. Community translocation in Britain: Setting objectives and measuring consequences. Biological Conservation 84 (3), 199-214 (1998)

3. TU Graz Institut für Wasserbau und Wasserwirtschaft, ATCOLD - Austrian National Committee on Large Dams. Pumped Storage Hydropower in Austria. 450 pp. (2018)

4. B. Bonapace. Tests and Measurements for the Pressure Tunnels and Shafts of the Sellrain-Silz Hydroelectric Power Scheme with extremely high head. Proceedings the $5^{\text {th }}$ ISRM Congress, Melbourne, Australia. Paper Number: ISRM-5CONGRESS-1983151 (1983)

5. P. Bauhofer, M. Zoglauer. Wasserkraftspeicher als Enabler der Energiewende. Beitrag zur IEWT 2019 (11. Internationale Energiewirtschaftstagung), TU Wien (2019)

6. K. Feistmantl, H. Pliessnig, M. Schletterer. Das Ausbauprojekt Speicherkraftwerk Kühtai - mit dem neuen Speicher im Längental. Archäologie Aktuell 2, 10-16 (2018)

7. F. Klötzli, E. Maltby. Mires on the move in Europe. The Geographical Magazine 85/7, 346-351 (1983)

8. F. Klötzli. Disturbance in Transplanted Grasslands and Wetlands. pp. 79-96 in: J. van Andel, P. Jan, R.W. Snaydon (Eds.): Disturbance in Grasslands, Dordrecht: Dr W. Junk Publishers (1987) 
9. O. Jönsson (2018). Ein Moor auf Reisen. Online: https://blogs.ethz.ch/digitalcollections/2018/04/23/ein-moor-auf-reisen/ (2018)

10. Flughafen Zürich. Natur und Landschaft. 18 pp., https://www.flughafenzuerich.ch/unternehmen/laerm-politik-und-umwelt/natur-und-landschaft (2020).

11. N. Wahlmüller, K. Oeggl. Vegetations- und Landnutzungsänderungen im Längental 2000 Jahre Almwirtschaft. FÖ Fundberichte aus Österreich 56, D207-D224 (2019)

12. J. Braun-Blanquet. Pflanzensoziologie. Grundzüge der Vegetationskunde. $3^{\text {rd }}$ Edition Springer Verlag Wien, 865 p., (1964)

13. S.M. Hennekens, J.H.J. Schaminée. Turboveg, a comprehensive database management system for vegetation data. Journal of Vegetation Science 12, 589-591 (2001) 